\title{
ANPEPP Conference: A View from an International Visitor
}

\section{O Simpósio da ANPEPP: Na Perspectiva de um Observador International}

\author{
Merry Bullock \\ American Psychological Association, Washington, D.C., United States
}

\begin{abstract}
This paper provides an overview from the perspective of an invited international guest to the $15^{\text {th }}$ Symposium of ANPEPP, held in Bento Gonçalves, Brazil, in May, 2014. ANPEPP, the acronym for "Associação Nacional de Pesquisa e Pós-Graduação em Psicologia," or the "Brazilian National Association for Research and Postgraduate Studies in Psychology" in English, is comprised of psychology faculty at postgraduate programs throughout Brazil. The theme of internationalization is especially relevant for Brazil, where there has been rapid development in science and technology output, affording it a new, emerging international role. The paper discusses the multiple connotations of internationalization, the goals for internationalization from different perspectives, and the impact of internationalization on psychological research and publishing in Brazil. It also addresses the opportunities and challenges of internationalization in Brazil and elsewhere. In addition, the author shares her experiences in the ANPEPP forum-plenary sessions and business meetings. Of particular note as a first-time attendee is the evaluation process for postgraduate education, conducted by CAPES, the Brazilian Federal Agency for Improvement of Higher Education. In closing, the author asks what psychology, as a discipline, can learn from ANPEPP's and Brazil's approach to developing and evaluating academic disciplines, and expresses appreciation for the opportunity to participate in what she characterizes as a unique convocation.
\end{abstract}

Keywords: ANPEPP, internationalization, Brazil, CAPES.

\section{Resumo}

O artigo traz uma visão global da perspectiva de um convidado international ao VX Simpósio da ANPEPP, realizado em Bento Gonçalves, Brasil, em maio de 2014. ANPEPP é a sigla para "Associação Nacional de Pesquisa e Pós-Graduação em Psicologia”, ou "The Brazilian National Associqation for Research and Postgraduate Studies in Psychology" em inglês, é constituída por professores de psicologia nos programas de pós-graduação de todo o Brasil. O tema da internacionalização é especialmente relevante para o Brasil, onde tem ocorrido rápido crescimento em ciência e tecnologia, conferindo-lhe um novo e emergente papel. O artigo discute as conotações múltiplas, os objetivos em suas várias perspectivas, e seu impacto na pesquisa e nas publicações brasileiras. Trata, ainda, das oportunidades e desafios da internacionalização no Brasil e em outros países. Ademais, a autora compartilhou suas experiências nos fóruns e nas reuniões administrativas ocorridas no evento. De particular interesse para quem participa do Simpósio ANPEPP pela primeira vez, foi a sistemática de avaliação da pós-graduação conduzida pela CAPES, a agência brasileira responsável pelo aperfeiçoamento do ensino superior. Concluindo, a autora pergunta o que a psicologia, como ciência, pode aprender com a ANPEPP e com o sistema brasileiro para o desenvolvimento e a avaliação das pós-graduações, e apresenta sua apreciação pela oportunidade de participar do que caracteriza como uma única e singular convocação.

Palavras-chave: ANPEPP, internacionalização, Brasil, CAPES, pós-graduação.

In May, 2014 I attended the $15^{\text {th }}$ ANPEPP Symposium for Scientific Interchange and Research (XV Simpósio Pesquisa e Intercâmbio Científico da ANPEPP). This is a biannual conference of the Brazilian National Association for Research and Graduate Studies in Psychology, an

Correspondence concerning this article should be addressed to Merry Bullock, American Psychological Association, 750 First Street NE, Washington DC 20002-4242, US; email: mbullock@apa.org organization that includes all the faculty who teach in psychology post-graduate programs. I was one of about five invited international guests.

The ANPEPP Symposium, held every two years, does not resemble the typical psychology conference with keynotes, talks, posters and roundtables. Rather, true to its name, it felt like a cross between an intense workshop and a reunion. The close to 1,300 attendees were psychology faculty at graduate programs, and some 
selected graduate students. The agenda reflected what I understood to be the major goals of the Symposium - to promote dialogue, collaboration and self-reflection in the Brazilian psychology research community.

The program consisted of an opening keynote talk (on the history of the Symposium and on the development of psychology research and postgraduate education in Brazil); 4 "forums" where all participants gathered to listen to talks on, and discuss, 4 "megaissues" of ethics, internationalization, science and policy, and internationalization and innovation in publishing; and smaller gatherings in over 60 different workgroups. There were also two large organizational meetings: a presentation of the regular evaluation of psychology graduate programs performed every three years by the Brazilian National Science Foundation, CAPES, and an ANPEPP General Assembly. These were complemented by social gatherings in coffee breaks, lunches, a reception, and a group dinner at a restaurant serving "typical" Ítalo-Brasileiro food.

The ANPEPP symposium is unique. What began as a meeting of representatives of graduate programs (the original symposium allowed three representatives from each program) has evolved into a forum that gathers most research-oriented faculty and that fosters collaboration within the Brazilian context. At the 2015 symposium there were 68 work groups, ranging from specific substantive issues (symbolic processes, assessment, evaluation) to investigation of processes (practices in institutions, health psychology in institutions, legal practices against violence) to groups addressing broad areas of psychology. The tasks of the work groups were varied - some developed curricula, some proposed books, some initiated research projects, some produced materials for the public - but each developed or worked on specific, concrete, anticipated outcomes. Apparently the number of work groups has grown steadily year by year, reflecting the diversity of Brazilian research interests.

As an outsider, and an outsider challenged in Portuguese, I can only comment on the broad brushstrokes of the Symposium content. Its form and structure, however, seemed suited to foster communication and collaboration, and to build consensus on the contents, evaluation, and directions of the discipline.

\section{The Forums}

My own direct participation was in two of the four Forums - sessions that were broad discussions on overarching issues. One was on internationalization of graduate programs; the other on internationalization and innovation in publishing (I was in the second one to represent APA Publisher Gary VandenBos, who provided an analysis on the status of journals and research in psychology from Latin America).

\section{The Internationalization Forum}

The focus of the internationalization forum was on definitions, measures, and ways to accomplish internationalization within the Brazilian psychology community. It also addressed the important issue of balancing internationalization with the responsibility of maintaining a national education system. I believe that Brazil, as a science community, is both committed to and focused on internationalization - it is a major criterion in the evaluation of graduate programs in psychology (and from what I understood pretty much the criterion that moves a program from just "good" to the two highest levels of evaluation). It is timely for it to be so - research production in Brazil has been increasing steadily, and is achieving world level impact. Brazilian researchers are encouraged both as students and as professionals to engage internationally through a variety of programs that promote exchange and international experiences.

In this context my remarks were quite general, and based on participation in many conversations about the meaning of internationalization in different countries.

Meaning of internationalization. A first point was that internationalization carries a number of meanings, each of which has implications for how a country, or a discipline, would pursue it. For many sciences, internationalization is the search for common universals, or standards; for others, it is a move toward harmonization or consensus. Psychology seems ambiguous in this regard - we do search for universals (in processes across cultures, languages, and countries), but at the same time we acknowledge and try to understand the ways in which culture, history, and context create seemingly incommensurate psychological constructs (see Bullock, 2012a, b).

Internationalization in psychology also carries different meanings depending on who is talking. For psychologists from those countries that have dominated the "mainstream" of psychology (e.g. the United States and to some extent European countries), internationalization generally has come to mean becoming more inclusive about research, models, and theories from other countries. The growing recognition that most psychological knowledge is based on a very small slice of the human population drawn from largely wealthy, western, developed countries (cf. Arnett, 2008; Henrich, Heine, \& Norenzayan, 2010) has led to an increased interest in expanding that base. Although the US and Europe still do dominate the psychology literature, and to some extent do export their theories and models, that is changing as we, as a discipline, recognize that international exchange is better seen as adaptation, not translation or adoption.

For psychologists from other countries, generally outside of Europe and North America, internationalization often has a more explicit goal of bringing one's national psychology to a broader context. In many countries, internationalization has a connotation of taking steps to "join" the "mainstream" of psychology, by publishing in 
"mainstream" journals, adopting mainstream standards or evaluation criteria, or increasing representation in international committees, boards or conferences.

These two different meanings, changing one's psychology by bringing new inputs in, or changing it by expanding outwards, have different implications for action. In the case of Brazil, from my observations, internationalization is generally discussed as extending Brazilian work outwards, increasing Brazilian representation in international settings, and encouraging active exchange inwards and outwards with scholars from outside of Brazil. Each of these actions requires Brazilian students and scholars to change their orientation - toward using English, toward publishing in "international" as opposed to local journals, and toward framing their work in a larger, more intercultural context, either as a unique example of cultural variation, or as confirmation of a more general norm.

But this carries an inherent tension, as the Forum discussion acknowledged, between local and universal perspectives. These tensions include balancing how to address local needs with local scholarship in local languages, with engagement at the international level on less localized issues and almost certainly in English. This is an especially important conversation within national universities, whose contract with the public is to serve important public education goals.

Goals of internationalization. The second point was that it is important to distinguish the goals of internationalization (greater voice, impact, more inclusion, richer science) from the metrics of internationalization. In many discussions of how to evaluate internationalization, including in the Brazilian system, the metrics are paramount and are primarily quantitative - numbers of journals, contacts, articles, collaborations, and the like.

These are important indicators, and help to provide a snapshot of some aspects of internationalization. But in my opinion, these indicators may overlook an important goal of internationalization - creating processes that allow the discipline to expand its knowledge, understanding, and explanations of human behavior. That is, the goals of internationalization are not just to increase citations or collaborations - the goals, are, or at least I believe should be, to create a process by which we can ground our knowledge, understanding, and explanations of human behavior, by placing them within a broad range of experiences across countries, cultures and contexts.

Challenges of internationalization. A first challenge is how to broadly support the psychology community in internationalization and in serving the local population. To the extent that internationalization requires working in a second, third, or fourth language, or negotiating unfamiliar publications outlets, the challenge is how to make these outlets accessible without disenfranchising local scholars or students, and without making the country's scientific output less accessible to its public.
A second challenge, especially in psychology, is between the search for universal constructs or common standards, guidelines or procedures and the need to acknowledge huge cultural differences in fundamental aspects of behavior such as identity, psychopathology, language, and cognitive skills. What has become clear is that we need to take especial care in identifying what we define as normative.

A third challenge in internationalization is trying to reach consensus on standards, guidelines, structures or definitions. The reality is that the organization of psychology and the relation of psychology to its local context is incredibly variable around the world. This means that it is never a good idea to adopt policies, structures or systems from one country to another without deep knowledge of how the other systems work. This is one of the underlying reasons for the "competency" movement in psychology as a way of defining the discipline and avoiding the tendency to compare educational systems or degree names as the basis for common mobility guidelines.

\section{Workgroups}

I attended one workgroup on developmental processes, which itself (after some discussion) separated into separate project groups. The one I listened to, cognitive processes, decided to work on theory of mind - participants had varied perspectives - and discussed working populations from preschool to the elderly - allowing a diverse perspective on the content and its application. Discussion was lively and exploratory. I visited another workgroup on history only briefly - one of the topics they were discussing was the discovery of psychological writings by a Brazilian psychologist, published well before the more well known European and American examples of Wilhelm Wundt and William James.

\section{Organizational and Other Meetings}

In addition to working groups, and the forum-plenaries, there were business meetings to present results and discussion about the Brazilian system of evaluation of individuals and institutions. The business meeting was particularly interesting. Every three years, CAPES, the Brazilian Federal Agency for the Support and Evaluation of Graduate Education, evaluates all graduate psychology programs. From my understanding, evaluations are completed in five areas of concern, encompassing 19 items and 57 indicators - the point is to evaluate program faculty, program students, program production (i.e., articles, books, professional service on boards and committees, and conferences), and social responsibility. Evaluations are performed by a commission of 25 peers. All programs are given a rating from 1 to 5 . Those rated at 5 are then eligible for higher ratings of 6 or 7 , which seemed to depend almost exclusively on the degree to which the program and faculty or students are considered "international" in output, orientation, or scope. The session where this was discussed 
was informative - in addition to presenting data on the close to 80 programs, discussion focused on challenges of increasing diversity in programs and orientation, on strategies for comparing programs that were different in structure and orientation, and on new directions that added technical indicators for internationalization, for social responsibility, and that attempted to shift evaluation from quantity to quality of programs.

I enjoyed the presentation of the data (which provided a reasonably thorough snapshot picture of programs, although there was some discussion that many programs do not take the care to properly present themselves), and I was especially intrigued by the discussion which addressed issues familiar from discussions of education in the US - a need to develop students to be good teachers as well as good researchers; a need to find ways to measure quality, not quantity, and (perhaps unique to the Brazilian system), ideas on how to simplify the evaluation process.

I was struck by the emphasis on internationalization - I had known that this was an important dimension to Brazilian programs (and the topic on which I was invited to comment as part of the program was internationalization), but did not realize how strongly it influences the system in evaluation and in aspiration.

Other highlights of the ANPEPP symposium were book presentations - many of the workgroup productions are books - which provide a consensually based view of Brazilian work and thinking in a range of areas in psychology, plus social events, including a gala dinner for attendees with local musical entertainment, as well as lively lunches and breaks, and broad conversations and interactions during the meals and breaks.

\section{What Can We Learn from ANPEPP?}

A model that supports regular meetings of the entire research community and that provides a structure to encourage collaboration across the psychology research and education community is, in my opinion, a very good model for the discipline. It's a meeting that "takes stock" in-house, but does so in ways to encourage and support excellence, and to encourage and support engagement in the system, not only in one's own local lab, program or university. Compared to analogous meetings in other places (COGDOP (Council of Graduate Departments of Psychology) in the US, for example) the ANPEPP symposium seems to have a primary focus on interuniversity or inter-colleague collaboration, rather than on management of programs (although this is addressed in the evaluation discussions).

It would not be possible to end this brief look at ANPEPP without noting the special hosting by the organizers. The ANPEPP president, members of the organizing committee, and other Brazilian colleagues made us feel most welcome, and provided opportunities to observe and interact with symposium attendees.
After close to a week of hearing conversation, discussion and presentations in Portuguese, I found myself increasingly drawn into conversations, and increasingly aware of some of the nuances of the meeting. And I was eager to learn more and to follow the development of this most remarkable convocation.

\section{References}

Arnett, J. (2008). The neglected 95\%: Why American psychology needs to become less American. American Psychologist, 63, 602-614.

Bullock, M. (2012a). De lo global a lo local: Las perspectivas actuales en la psicología (from the Global to the Local: Current Directions in Psychology). Boletin Psicologia Interamericana 94, December.

Bullock, M. (2012b). International Psychology. In D. Freedheim \& I. Weiner (Eds.), Handbook of Psychology, Volume 1: History of psychology (2nd ed.) (pp. 562-596). Hoboken, NJ, US: John Wiley \& Sons.

Henrich, J., Heine, S., \& Norenzayan, A. (2010). The weirdest people in the world? Behavior and Brain Sciences, 33, 61-83. 